\title{
Team Member Effectiveness and Employee Performance in a Telecommunication Organization
}

\author{
${ }^{1}$ Norliya Ahmad Kassim, ${ }^{1}$ Kasmarini Baharuddin, ${ }^{2}$ Mohd Rosnizan Baba \\ ${ }^{1}$ Faculty of Information Management, Universiti Teknologi MARA, Selangor, Malaysia \\ ${ }^{2}$ TELEKOM Malaysia Sdn Bhd, Kuala Lumpur, Malaysia
}

\begin{abstract}
The purpose of the study is to investigate factors of team member effectiveness (TME) namely enablement, engagement and interaction toward employee performance among technical team at one telecommunication organization in Malaysia. A research survey method using questionnaire was distributed to 130 technical team members of the organization. The results of the survey were analyzed using the Statistical Package for the Social Sciences (SPSS). From the findings, the three TME dimensions and employee performance mean score were acquired. Specifically, the TME dimension on engagement was ranked as the highest as perceived by respondents (mean=3.511), followed by enablement (mean=3.431) and interaction (mean=3.331), while for employee performance the mean is 3.456. The results are important to the organization to provide significant feedback on technical team on factors of team member effectiveness and employee performance which is useful for organization to enhance organizational learning.
\end{abstract}

\section{Introduction}

Team member effectiveness affects task routine and indicates the team performance and team viability. Team performance reflects the team's ability to fulfill the assigned tasks. Team viability represents the team's ability to function adequately over time, and team process improvement corresponds to the team's ability to enhance task outputs by introducing new or refined practices [1],

[2], [3], [4]. Team member effectiveness will enhance team self-behavior and team process performance in which team members need to accomplish particular tasks as defined by the organization [5], [6]. Team member effectiveness is related to task accomplishment, such as enablement to each member, engagement work activities, financial success and monitoring interaction among team. Team member effectiveness provides value in team and self-monitoring. It gathers information concerning the team's function and progress toward specified goals [7].
The relationships between team member effectiveness and employee performance will enable to prevent or respond to changing demands within their environment [8]. The employee performance will enhance the quality of their products or services, reduce delivery time, and cut production costs [9]. The employee performance can influence in developing an appropriate response to situations where performance can be enhanced or reduced. Good employee performance can give impact to produce highly routine tasks that represent predictable situations that can be resolved using standardized procedures. Employee performance help people to quickly form impressions which help people use their own past experience to guide new interactions.

Most companies realize the potential and influence of team member effectiveness in the organization that is necessary to remain viable in the increasingly competitive business world. Team member effectiveness enhanced organizational performance by drawing on the talents of the workforce and using these people to the full. The Team Management Wheel provides an integrated map of people's work preferences and relates them to the key roles that are necessary in a high performing team [10]. Consequently, companies and academics have increasingly focused on enhancing team member effectiveness and build a training company. It seems to be difficult to conclude that one can prove the team member effectiveness toward the employee performance among technical team.

The technical team will be a multidisciplinary team that includes experts in all of the core values. However, nowadays, their task have been challenged by technical team work with software companies and information technology firms with their job descriptions involving provision of solutions to emerging technical issues facing the advancement of their organizations' products and services. The lack of team member effectiveness among technical team is more challenging when the technical team needs to update the skills of the nature of the job. The technical team needs to interact and exchange ideas with project leaders and other members of the team in a bid to arrive at good designs and solutions in the online system as information services on the management. The benefits of information services 
can help users to get the right information and also to enhance their understanding and user efficiency. A work team includes at least two individuals who are interdependent and collectively responsible for accomplishing particular tasks as defined by the organization [5], [6].

This research addresses three factors of team members' effectiveness which are: enablement, engagement and interaction. The objectives of this study are to examine factors of team member effectiveness namely enablement, engagement and interaction and analyze employee performance among technical team in a telecommunication organization.

\section{Literature Review}

\subsection{Team Member Effectiveness}

Team member effectiveness is about working in teams in building organization for accomplishing particular tasks. Team-based organizations may rely on team members to self-manage their work activities [11], [12]. Team member effectiveness with self-management has shown that selfmanagement as a feature of job design has inconsistently predicts criteria of team effectiveness [13]. Team member effectiveness affects task routine of such team's ability to fulfill the assigned tasks, the team's ability to function adequately over time and the team's ability to enhance task outputs by introducing new or refined practices [1], [2], [3], [4].

Team member effectiveness takes responsibilities to achieve and accomplish the goals of team member by exhibiting notably self-planning, Self-monitoring, self-reinforcement, and self-adjustment [14], [15], [16], [17], [18], [19]. Team performance may be enhanced by teamwork processes inherent to selfmanagement, such as goal specification, strategy formulation, monitoring progress, system monitoring, and team monitoring [20].

Team member effectiveness has task routine that reflects the extent to which individuals do their work in a consistent or repetitive fashion [21], [22]. The effective performance requires team members to apply standard operating procedures [22]. The selection of work teams was based on four criteria [6], [23], [24]. Specifically, these criteria imply that the members of a team (a) constitute a formal group in the organization; (b) have team goals to accomplish; (c) execute tasks that are connected to the mission of the organization; and (d) are interdependent in task accomplishment.

The multiple-source study shows that lean work teams are more effective when their leaders endorse self-transcendence and reject conservation values while their employees share a lot of information. More research on the human factors on lean work floors is warranted, given also that many other change-management practices pivot on work-floor employees as crucial informants for enhancing organizational or team effectiveness [25], [26].

Through the development of effective ways of thinking, Self Management Teams (SMT) can prevent harmful thinking patterns like groupthink and achieve desirable performance and sustainability [27]. In SMTs, team thought self-leadership seems to prompt the group's ability to engage in more effective thinking. The increase in SMTs quality of thinking patterns seems to positively predict team collective efficacy. This finding is in line with previous research suggesting how work groups think about their ability to overcome obstacles, or conclude work related tasks, is heavily influenced by their thoughts regarding their current situation [28].

The team effectiveness model by [29] adopts the IPO structure, while acknowledging the significance of the organizational and situational context throughout the entire process, as well as incorporating feedback loops. [30] adapted a structure similar to the one presented by [29]. Organizational and situational characteristics are considered important to the overall team's performance. [30] suggest that task and work characteristics help identify individual and team competencies that affect team performance. Similar to the previous model, this model highlights the importance of team and task competencies in team training and performance.

The definition of employee enablement as offered by the Economist Intelligence Unit [31] with that of Hay Group [32], is the extent to which employees feel they are provided with what they need to do their jobs well and are provided with an environment in which they feel comfortable to perform to the best they can be.

Employee engagement is a vast construct that touches almost all parts of human resource management facets. If every part of human resources is not addressed in appropriate manner, employees fail to fully engage themselves in their job in the response to such kind of mismanagement. The construct on employee engagement is built on the foundation of earlier concepts like job satisfaction, employee commitment and organizational citizenship behavior. Though it is related to and encompasses these concepts, employee engagement is broader in scope. Employee engagement is a stronger predictor of positive organizational performance and it clearly shows the two-way relationship between employer and employee compared to the three earlier constructs: job satisfaction, employee commitment and organizational citizenship behaviour. Engaged employees are emotionally attached to their organization and highly involved in their job with a great enthusiasm for the success of their employer 
and going extra mile beyond the employment contractual agreement [33].

[34] recognized that most organizations have "pockets of people somewhere" who can act as change agents through their initiatives, interactions and small adjustments to the environment. Organizational change may thus occur locally [35], [36], [37] as certain individuals reflect on circumstances and experiences and decide, more or less consciously, to intervene to adjust or change organizational practices and policies. In this perspective, the changes that actors implement following their reflection are anchored not only in their interactions with other actors (e.g. colleagues or managers), but also in their perceptions and interpretations of the behaviors of these other actors [38].

\subsection{Employee Performance}

Employee performance relates to the activities of what organizations can do to cause employees to produce great work, what organizations currently do to motivate employees, and how effective each is at causing employees to produce great work. Employee is a key element of the organization. The success or failure of the organization depends on employee performance. Employee development means to develop the abilities of an individual employee and organization as a whole; hence employee development consists of individual or employee and overall growth of the employee as when employees of the organization would develop the organization, organization would be more flourished and the employee performance would increase [39].

Employee performance will reduce if conflict happens. According to a study by [40], conflict is a state in which two or more parties have incompatible objectives and in which their perception and behavior is appropriate with that incompatibility. Conflict occurs due to difference of perception, ideas, behaviors, interest, attitudes, religious differences, political differences and unjustified distribution of national resources. Conflict is not always negative. It depends how the conflict is handle. If handled properly, it can become source of development; otherwise it creates hostilities [41]. So it affects quality, performance and profit of organization. Conflict is essential for life and dynamic for team performance [42]. When managers ignore the clash between the co-workers, those clashes will be converted into personal and emotional conflict in the long run and therefore damages the organizational culture, workers' morale and overall reduction of organizational performance.

\section{Methods}

Specially, this quantitative study aims to describe the factors of team member effectiveness which are enablement, engagement and interaction towards employee performance among technical team at one telecommunication organization in Malaysia. The population chosen in this study involved technical team at network delivery located at TM Bukit Anggerik, TM Serdang and TM Petaling Jaya. The respondents were selected randomly from the sampling frame. The population of this study was 130, thus applying [43] for determining sample size from a given population. In this study, questionnaire was used in order to collect the data. A total of 130 questionnaires were distributed personally by the researcher to the technical team in their workplace. The questionnaires were collected personally by the researcher after the respondents answered the questionnaires. To make sure that the questionnaire is valid and reliable, pretest, validity test, pilot study and reliability test have been performed. After the questionnaires were returned by the respondents, data analysis process was conducted. Descriptive statistics including frequency, percentage, mean and standard deviation were performed.

\section{Results}

\subsection{Profile of Respondent}

Distribution of respondents by gender shows that majority (91 or $70 \%$ ) of the respondents are male while $39(30 \%)$ are female. Distribution of respondents by age shows that the higher age percentage of respondents are between 31-40 years (46.9\%), $22.3 \%$ aged more than 50 years, $18.5 \%$ are 41-50 years and $12.3 \%$ of the respondents are $21-30$ years old. Majority (93 or $71.5 \%$ ) of the respondents are non-executive staff and $37(28.5 \%)$ are executive staff.

By their educational level, more than half of the respondents have diploma (61 or $46.9 \%$ ) while 25 or $19.2 \%$ have certificate, about a third (40 or $30.8 \%$ ) of the respondents have a Degree (40 or $30.8 \%$ ) and only 4 or $3.1 \%$ have a Master Degree. $38(29.2 \%)$ of the respondents have below 10 years of working experience, $47(36.2 \%)$ of the respondents have 1120 years of working experience and 45 (34.6\%) of the respondents have more than 21 years of working experience.

Distribution of respondents by department displays that $18(13.8 \%)$ of the respondent are in the Support Department, 36 (27.7\%) of the respondents are in the Integrated Planning, 45(34.6\%) of the respondents are in Detail Planning and 31 (23.8\%) of 
the respondents are in the Implementation Department.

\subsection{Reliability Test}

In this study, reliability tests were calculated using the Cronbach's alpha which is considered as the most appropriate statistical test for reliability measurement. Cronbach's alpha reliability coefficient normally ranges between 0 and 1 . The closer the Cronbach's alpha coefficient is to 1.0 the greater the internal consistency of the items in the scale. [44] provide the following rules of thumb: " > 0.9 - excellent, .> 0.8 - Good, > 0.7 -acceptable, > 0.6 - Questionable, > 0.5 - Poor and $<0.5-$ Unacceptable".

Table 1. Reliability Test Results

\begin{tabular}{|l|c|c|}
\hline Variables & $\begin{array}{l}\text { Number of } \\
\text { statement }\end{array}$ & $\begin{array}{l}\text { Cronbach's } \\
\text { Alpha }\end{array}$ \\
\hline Enablement & 5 & 0.866 \\
\hline Engagement & 5 & 0.813 \\
\hline Interaction & 4 & 0.753 \\
\hline $\begin{array}{l}\text { Employee } \\
\text { Performance }\end{array}$ & 5 & 0.809 \\
\hline
\end{tabular}

In this study, the results from the computed Cronbach's alpha showed that all independent variables and dependent variable are more than 0.70 in which the reliability level is acceptable (see Table 1). The reliability coefficient of Team member effectiveness dimensions for enablement is $\operatorname{good}(\alpha=$ $0.866)$, Engagement is good $(\alpha=0.813)$, Interaction is slightly good $(\alpha=0.753)$ and Employee performance is good $(\alpha=0.809)$.

\subsection{Perception on Team Members Effectiveness (TME)}

This section presents the results of data analysis on the respondents' agreement with regards to various dimensions of TME. The respondents agreement were measured in a Likert scale of 1 to 5 : (1) Strongly Disagree, (2) Disagree, (3) Quite Agree, (4) Agree and (5) Strongly Agree. In this study, the whole sample of 130 respondents consisting of managerial and technical were used.

\subsubsection{Level of Team Member Effectiveness Dimensions (Enablement, Engagement and Interaction). Research Question 1: What are the factors of team member effectiveness namely enablement, engagement and interaction among technical team in network delivery at TM Bukit Anggerik, TM Serdang \& TM Petaling Jaya?}

Table 2. Mean Score for Enablement

\begin{tabular}{|c|c|c|c|}
\hline & Statement & Mean & Std.Deviation \\
\hline 1 & $\begin{array}{l}\text { The knowledge of } \\
\text { employees give } \\
\text { benefits to } \\
\text { improve the } \\
\text { efficiency of a } \\
\text { business process }\end{array}$ & 3.631 & 0.855 \\
\hline 2 & $\begin{array}{l}\text { The capabilities } \\
\text { and knowledge of } \\
\text { employees } \\
\text { influence the } \\
\text { employee } \\
\text { performance }\end{array}$ & 3.631 & 0.799 \\
\hline 3 & $\begin{array}{l}\text { I have access to } \\
\text { the things I need to } \\
\text { do my job well }\end{array}$ & 3.431 & 0.646 \\
\hline 4 & $\begin{array}{l}\text { I have access to } \\
\text { the learning and } \\
\text { development skill } \\
\text { I need to do my } \\
\text { current job } \\
\text { effectively }\end{array}$ & 3.262 & 0.699 \\
\hline 5 & $\begin{array}{l}\text { Most of the } \\
\text { systems and } \\
\text { processes here } \\
\text { support us in } \\
\text { getting our work } \\
\text { done effectively }\end{array}$ & 3.200 & 0.782 \\
\hline & $\begin{array}{l}\text { Overall mean for } \\
\text { enablement }\end{array}$ & 3.431 & 0.756 \\
\hline
\end{tabular}

Table 2 displays the mean scores and standard deviations (SD) of factors of team member effectiveness on the dimension: enablement. The overall mean score is 3.431 and standard deviation is 0.756 which indicates that respondents quite agree with the statement on enablement. The mean scores for all items are between 3.631 to 3.20 and these indicate that they agree and quite agree with all the statements. Among the five statements, the mean scores are highest for two statements: the capabilities and knowledge of employees influence the employee performance and the knowledge of employees give benefits to improve the efficiency of a business process $($ mean $=3.631)$ followed by $I$ have access to the things I need to do my job well (mean=3.431). The second lowest mean score is I have access to the learning and development skill I need to do my current job effectively (mean=3.262) and the very lowest mean score is most of the systems and processes here support us in getting our work done effectively (mean=3.200). This indicates that respondents quite agree that the organization has reached the team members effectiveness with respect to enablement. Overall, it can be concluded that respondents have positive perception that their 
organization has reached the level of team member effectiveness with regards to enablement

Table 3. Mean Score for Engagement

\begin{tabular}{|c|c|c|c|}
\hline & Statement & Mean & $\begin{array}{c}\text { Std. } \\
\text { Deviation }\end{array}$ \\
\hline 1 & $\begin{array}{l}\text { Doing my job well } \\
\text { gives me a sense of } \\
\text { personal satisfaction }\end{array}$ & 3.692 & 0.786 \\
\hline 2 & $\begin{array}{l}\text { There is a strong } \\
\text { feeling of teamwork } \\
\text { and cooperation in } \\
\text { this organization }\end{array}$ & 3.492 & 0.650 \\
\hline 3 & $\begin{array}{l}\text { In this organization } \\
\text { we maintain very } \\
\text { high standards of } \\
\text { quality }\end{array}$ & 3.462 & 0.637 \\
\hline 4 & $\begin{array}{l}\text { We work to attract, } \\
\text { develop, and retain } \\
\text { people with diverse } \\
\text { backgrounds }\end{array}$ & 3.462 & 0.637 \\
\hline 5 & $\begin{array}{l}\text { Information and } \\
\text { knowledge are } \\
\text { shared openly within } \\
\text { this organization }\end{array}$ & 3.446 & 0.748 \\
\hline & $\begin{array}{l}\text { Overall mean for } \\
\text { engagement }\end{array}$ & 3.511 & 0.682 \\
\hline
\end{tabular}

Table 3 shows the overall mean score is 3.511 and the standard deviation is 0.682 which indicates that respondents quite agree with the statements on engagement. The mean scores for all items are between 3.692 to 3.446 and these indicate that they quite agree with all the statements. Among the five statements, the mean score is highest for doing my job well gives me a sense of personal satisfaction (mean=3.692) followed by there is a strong feeling of teamwork and cooperation in this organization (mean=3.492). Two statements have the same mean score (3.462 respectively) which are: we work to attract, develop, and retain people with diverse backgrounds and in this organization we maintain very high standards of quality. The lowest mean score is information and knowledge are shared openly within this organization (mean=3.446). This indicates that respondents quite agree that the organization has reached the team member effectiveness with respect to engagement. Overall, it can be concluded that respondents have positive perception that their organization has reached the level of team member effectiveness with regards to engagement.
Table 4. Mean Score for Interaction

\begin{tabular}{|c|c|c|c|}
\hline & Statement & Mean & $\begin{array}{c}\text { Std. } \\
\text { Deviation } \\
\end{array}$ \\
\hline 1 & $\begin{array}{lr}\text { The } & \text { job } \\
\text { requirements } & \text { and } \\
\text { job position are } \\
\text { clear }\end{array}$ & 3.385 & 0.627 \\
\hline 2 & $\begin{array}{l}\text { My organization } \\
\text { easily } \\
\text { communicates the } \\
\text { goals and strategies } \\
\text { to the team } \\
\text { members }\end{array}$ & 3.377 & 0.650 \\
\hline 3 & $\begin{array}{l}\text { My organization } \\
\text { gives opportunity to } \\
\text { interact with other } \\
\text { employees on a } \\
\text { formal level. }\end{array}$ & 3.377 & 0.626 \\
\hline 4 & $\begin{array}{l}\text { The management } \\
\text { gives a clear path } \\
\text { for career } \\
\text { advancement }\end{array}$ & 3.185 & 0.632 \\
\hline
\end{tabular}

Table 4 depicts the overall mean score of 3.331 and the standard deviation is 0.634 which indicates that respondents quite agree with the statements on interaction. The mean scores for all items are between 3.385 to 3.185 and these indicate that they quite agree with all the statements. Among the four statements, the mean score is highest for the job requirements and job position are clear (mean=3.385) followed by my organization easily communicates the goals and strategies to the team members and my organization gives opportunity to interact with other employees on a formal level (mean=3.377 respectively). The statement on the management gives a clear path for career advancement (mean=3.185) is the lowest. However, it all indicates that respondents quite agree that the organization has reached the team member effectiveness with respect to interaction. Overall, it can be concluded that respondents have positive perception that their organization has reached the level of team member effectiveness with regards to interaction.

\subsection{Employee Performance}

\subsubsection{Perception on Employee}

Performance. Research Question 2: What is the employee performance among technical team in the Network Delivery at TM Bukit Anggerik, TM Serdang and TM Petaling Jaya? 
Table 5. Mean Score for Employee Performance

\begin{tabular}{|c|c|c|c|}
\hline & Statement & Mean & $\begin{array}{c}\text { Std. } \\
\text { Deviation }\end{array}$ \\
\hline 1 & $\begin{array}{l}\text { Employees } \\
\text { share } \\
\text { information and } \\
\text { new ideas } \\
\text { throughout the } \\
\text { company }\end{array}$ & 3.523 & 0.625 \\
\hline 2 & $\begin{array}{l}\text { Employees are } \\
\text { committed to } \\
\text { serve the } \\
\text { organization }\end{array}$ & 3.477 & 0.587 \\
\hline 3 & $\begin{array}{l}\text { The } \\
\text { organizational } \\
\text { culture } \\
\text { enhances } \\
\text { employee } \\
\text { commitment }\end{array}$ & 3.438 & 0.635 \\
\hline 4 & $\begin{array}{l}\text { Team members } \\
\text { have positive } \\
\text { attitude toward } \\
\text { change and } \\
\text { they look } \\
\text { forward to do } \\
\text { new things }\end{array}$ & 3.423 & 0.541 \\
\hline 5 & $\begin{array}{l}\text { Employees } \\
\text { develop new } \\
\text { skills }\end{array}$ & 3.408 & 0.679 \\
\hline & $\begin{array}{l}\text { Overall mean } \\
\text { for employee } \\
\text { performance }\end{array}$ & 3.456 & 0.613 \\
\hline
\end{tabular}

Table 5 displays the overall mean score of 3.456 and the standard deviation is 0.613 which indicates that respondents quite agree with the statements on employee performance. The mean scores for all items are between 3.523 to 3.408 and these indicate that they quite agree with all the statements. Among the four statements, the mean score is highest for employees share information and new ideas throughout the company (mean $=3.523$ ) followed by employees are committed to serve the organization (mean $=3.477$ ). The second lowest mean score is the organizational culture enhances employee commitment $($ mean $=3.438)$ and the lowest mean score is team members have positive attitude toward change and they look forward to do new things (mean=3.423). This indicates that respondents quite agree that the organization has reached the team member effectiveness with respect to employee performance. Overall, it can be concluded that respondents have positive perception that their organization has reached the level of team member effectiveness with regards to employee performance.
4.5. Team Member Effectiveness and Employee Performance among Network Delivery at TM Bukit Anggerik, TM Serdang and TM Petaling Jaya

This section summarized the mean score (Table 6) of the three dimensions of team member effectiveness and employee performance as perceived by technical team of Network Delivery, at TM Bukit Anggerik, TM Serdang and TM Petaling Jaya.

Table 6. Mean Score of the Three TME Dimensions and Employee Performance

\begin{tabular}{|l|c|}
\hline $\begin{array}{c}\text { Three Dimensions of TME } \\
\text { and Employee } \\
\text { Performance }\end{array}$ & Mean Score \\
\hline Engagement & 3.511 \\
\hline Enablement & 3.431 \\
\hline Interaction & 3.331 \\
\hline Employee performance & 3.456 \\
\hline
\end{tabular}

The respective dimensions are measured by the aggregated mean of the 5 point Likert Scale item (see Table 6). The result depicts that on the average, the factors of the respondents on the three dimensions of TME and employee performance are quite similar and positive as they fall within a very short range of between 3.331 to 3.511. Engagement has the highest score (3.511), followed by Enablement (3.431) and Interaction (3.331). On the other hand, Employee Performance as the dependent variable accounted a mean score of 3.456 .

\section{Discussions}

This study has examined the TME dimensions and employee performance in the Network Delivery at TM Bukit Anggerik, TM Serdang and TM Petaling Jaya. This study also revealed the factors of TME dimensions with regard to employee performance. This section provided discussions with regards to answer the research questions and accomplish the research objectives. The level of factors on TME dimensions and employee performance are measured by the overall mean of variables.

In examining the factors on enablement in Network Delivery at TM Bukit Anggerik, TM Serdang and TM Petaling Jaya, majority of the technical team agree that they have access to the learning and development skill that they need to do their current job effectively. Furthermore, most of the systems and processes support them in getting their work done effectively. It can be assumed that 
the Network Delivery at TM Bukit Anggerik, TM Serdang and TM Petaling Jaya have realized the importance of knowledge employees in their organization. When organization embedded good enablement within their organization it will give good impact to all their employees.

In this study, it was found that the organization encouraged their employees to have access to the things employees need to do their job well. Thus, it can be assumed that the Network Delivery at TM Bukit Anggerik, TM Serdang and TM Petaling Jaya practiced enablement to encourage their employees to share new ideas or knowledge among them so that they can have better understanding about their organization's functionality. Most statements were positively rated by the technical teams where they quite agree that enablement took place in their organization. This implied that the technical teams in the organization are positive with the enablement implemented in their organization.

Engagement played a vital role in ensuring TME in performing effectively in the organization. With regards to the objective of the study, the technical teams are positive that doing their job well gave them a sense of personal satisfaction. Engagement is important in an organization and in the Network Delivery at TM Bukit Anggerik, TM Serdang and TM Petaling Jaya, the engagement allows employees to change the meaning of their work or their work identity by modifying characteristics of the job and the social work environment. There is also accumulated evidence that job crafting has a positive impact on individual well-being and job performance [45][46][47]. The study also found that there was a strong feeling of teamwork and cooperation in their organization.

This study also seeks to identify the technical factors on the practice of interaction in their organization. Interaction is another essential element in measuring TME in the organization. The employees' emotions may influence customers' behaviors during the customer service interaction through the conscious or unconscious induction of behavioral attitudes [47]. Most statements were positively rated by technical teams on the factors on interaction.

In determining the factors on the practice of interaction in the Network Delivery at TM Bukit Anggerik, TM Serdang and TM Petaling Jaya, majority of the technical teams agree that the job requirements and job position are clear. Therefore, this might indicate that technical teams in the Network Delivery at TM Bukit Anggerik, TM Serdang and TM Petaling Jaya are clear about their job position on working so that in the organization employees easily communicates with other employees. The findings of the study indicate that their organization easily communicates the goals and strategies to the team members and their organization gave opportunity to interact with other employees on a formal level. It is assumed that from the communication between the technical teams, it can develop better understanding and encouraged sharing of ideas.

With regards to employee performance, the findings show that the technical teams have positive perception that employees share information and new ideas throughout the company. Hence, it is assumed that technical teams are satisfied with their current organization's working environment and that will encourage them to work effectively and improve their employee performance. Employee performance is considered to be a central concept in organizations, as it mediates the relation between working conditions on one hand and organizational and individual outcomes on the other [48].

This study found that the technical teams have positive attitude toward change and they looked forward to do new things. When a technical team has a good relationship with their organizational culture, they tend to reach the level of job satisfaction. [49] contended that job characteristics such as pay, promotional opportunity, task clarity and significance, and skills utilization, as well as organizational characteristics such as commitment and relationship with supervisors and co-workers have significant effects on employee performance. Most statements were positively rated by the technical team. Therefore, this implied that technical team in the organization agreed that their organization has reached the level of employee performance.

\section{Conclusion}

Overall, it can be concluded that, the level of TME dimensions and employee performance is at medium level and in general the response is considered positive from the technical team in Network Delivery at TM Bukit Anggerik, TM Serdang and TM Petaling Jaya. It can be seen that, to enhance TME in an organization, one must see it as total. The implications of the study is that, although engagement plays an important role in an organization, without proper attention paid to enablement and interaction, TME in an organization cannot be successfully enhanced. Thus, enablement, engagement and interaction should always be taken into considerations.

It can be concluded that, the positive results of technical team factors on TME are an indication of the right lane towards a better employee performance in the Network Delivery at TM Bukit Anggerik, TM Serdang and TM Petaling Jaya. Furthermore, the outcome of the study is expected to improve the skills of acquiring knowledge and enhance the team member effectiveness of technical team in Network Delivery organization. 
On the practical side of the implication of the study, the results of this study will give feedback to the management of Network Delivery, TM Sdn Bhd the extent of their awareness towards team member effectiveness (TME) and employee performance. From the results, it can also provide with a clear view of the effectiveness and productivity of an organization depending on the development and nurturing of their staff. The results can also show that there are three TME dimensions that can be considered as vital toward employee performance among technical team of TM. The Network Delivery, TM Sdn Bhd will find out that by having this research it can actually contribute to the awareness regarding the importance of the TME toward employee performance. Thus, the Network Delivery, TM will be prepared to initiate some fundamental changes across certain aspects of the organization's operations.

Furthermore, the findings consequently had delivered a clear insight for the policy makers, management of companies and higher learning institutions in strengthening their knowledge management programs on organizational learning. Learning and knowledge management models can be adopted to attain the effectiveness of organizational capabilities as well as employee performance among technical team in Network Delivery, TM Sdn Bhd. The outcome of the study is expected to improve the skills of acquiring knowledge and enhance the learning capabilities not only among technical team and managerial team in the Network Delivery, TM Sdn Bhd only but also other all organizations in TM Malaysia Berhad.

\section{References}

[1] B. L. Kirkman, B. Rosen, P. E. Tesluk, and C. B. Gibson, "The Impact of Team Empowerment on Virtual Team Performance: The Moderating Role of Face-To Face Interaction", Academy of Management Journal, vol.47, pp.175-192, 2004.

[2] S. W. J. Kozlowski, and D. R. Ilgen, "Enhancing the Effectiveness of Work Groups and Teams", Psychological Science in the Public Interest, vol.7, pp.77-124, 2006.

[3] J. Mathieu, M. T. Maynard, T. Rapp, and L. Gilson, "Team Effectiveness 1997-2007: A Review of Recent Advancements and a Glimpse into the Future", Journal of Management, vol.34, pp. 410-476, 2008.

[4] A. G. Tekleab, N. R. Quigley, and P. E. Tesluk, "A Longitudinal Study of Team Conflict, Conflict Management, Cohesion, and Team Effectiveness", Group \& Organization Management, vol.34, pp.170-205, 2009.

[5] D. L. Gladstein, "Groups in context: A model of task group effectiveness", Administrative Science Quarterly, vol.29, pp.499-517, 1984.
[6] E. Sundstrom, K. P. De Meuse, and D. Futrell, "Work Teams: Applications and Effectiveness", American Psychologist, vol.45, pp.120-133, 1990.

[7] M. A. Marks, and F. J. Panzer, "The Influence of Team Monitoring on Team Processes and Performance", Human Performance, vol.17, pp.25-41, 2004.

[8] C. S. Burke, K. C. Stagl, C. Klein, G. F. Goodwin, E. Salas, and S. M. Halpin, "What type of leadership behaviors are functional in teams?", Leadership Quarterly, vol.17, pp.288-307, 2006.

[9] J. B. Fuller, L. E. Marler, and K. Hester, "Promoting Felt Responsibility for Constructive Change and Proactive Behavior: Exploring Aspects of an Elaborated Model of Work Design", Journal of Organizational Behavior, vol.27, pp.1089-1120, 2006.

[10] C. Margerison, and D. McCann, Team Management, London: W. H. Allan, 1990.

[11] F. P. Morgeson, M. D. Johnson, M. A. Campion, G. J. Medsker, and T. V. Mumford, "Understanding Reactions to Job Redesign: A Quasi-Experimental Investigation of The Moderating Effects of Organizational Context on Perceptions of Performance Behavior", Personnel Psychology, vol.59, pp.333-363, 2006.

[12] H. Van Mierlo, C. G. Rutte, M. A. J. Kompier, and H. A. C. M. Doorewaard, "Self-Managing Teamwork and Psychological Well-Being: Review of A Multilevel Research Domain", Group \& Organization Management, vol.30, pp.211-235, 2005.

[13] G. L. Stewart, “A Meta-Analytic Review of Relationships between Team Design Features and Team Performance", Journal of Management, vol.31, pp.319335, 2006.

[14] M. Castaneda, T. A. Kolenko, and R. J. Aldag, "SelfManagement Perceptions and Practices: A Structural Equations Analysis", Journal of Organizational Behavior, vol.20, pp.101-120, 1999.

[15] C. J. Lambe, K. L. Webb, and C. Ishida, "SelfManaging Selling Teams and Team Performance: The Complementary Roles of Empowerment and Control", Industrial Marketing Management, vol.38, pp. 5-16, 2009.

[16] L. G. Militello, M. M. Kyne, G. Klein, K. Getchell, and M. Thordsen, "A Synthesized Model of Team Performance", International Journal of Cognitive Ergonomics, vol.3, pp.131-158, 1999.

[17] V. Rousseau, C. Aubé, and A. Savoie, "Teamwork Behaviors: A Review and an Integration of Frameworks", Small Group Research, vol.37, pp.540-570, 2006.

[18] J. Tata, and S. Prasad, "Team Self-Management, Organizational Structure, and Judgments of Team Effectiveness", Journal of Managerial Issues, vol.16, pp.248-265, 2004.

[19] R. Wageman, "How Leaders Foster Self-Managing Team Effectiveness: Design Choices Versus Hands-On 
Coaching", Organization Science, vol.12, pp.559-577, 2001.

[20] J. A. LePine, R. F. Piccolo, C. L. Jackson, J. E. Mathieu, and J. R. Saul, "A Meta-Analysis of Teamwork Processes: Tests of a Multidimensional Model and Relationships with Team Effectiveness Criteria", Personnel Psychology, vol.61, pp.273-307, 2008.

[21] J. M. Diefendorff, E. M. Richard, and R. H. Gosserand, "Examination of Situational and Attitudinal Moderators of The Hesitation and Performance Relation", Personnel Psychology, vol.59, pp.365-393, 2006.

[22] C. K. W. De Dreu, and L. R. Weingart, "Task Versus Relationship Conflict, Team Performance, and Team Member Satisfaction: A Meta-Analysis", Journal of Applied Psychology, vol.88, pp.741-749, 2003.

[23] J. R. Hackman, The Design of Work Teams. In Lorsch, J. W. (ed.). Handbook of organizational Behaviour, Englewood Cliffs, NJ: Prentice Hall, 1987.

[24] D. R. Ilgen, "Teams Embedded In Organizations: Some Implications", American Psychologist, vol.54, pp.129-139, 1999.

[25] J. Bicheno, and M. Holweg, The Lean Toolbox, Picsie Books, 2009.

[26] E. De Lange-Ros, and H. Boer, "Theory and Practice of Continuous Improvement In Shop- Floor Teams", International Journal of Technology Management, vol.22, pp. 344-358, 2001.

[27] C. Neck, and C.P. Manz, "From Group Think to Team Think: Toward the Creation of Constructive Thought Pattern in Self-Managing Work Teams", Human Relations, vol.47, pp.929-952, 1994.

[28] G. E.Prussia and A. J. Kinicki, "A Motivational Investigation of Group Effectiveness Using Social Cognitive Theory", Journal of Applied Psychology, vol. 81, pp.187-198, 1996.

[29] S. I. Tannenbaum, R. L. Beard, and E. Salas, "Team Building and Its Influence on Team Effectiveness: An Examination of Conceptual and Empirical Developments", Organizational Psychology, pp.117-153. New York: Elsevier Science, 1992.

[30] J. A. Cannon, S. I. Tannenbaum, E. Salas, and C. E. Volpe, Defining Team Competencies: Implications For Training Requirements and Strategies Team Effectiveness and Decision Making in Organizations. San Francisco: Jossey Bass, 1995.

[31] W. Wright, Ready, Willing And Enabled: A Formula For Performance, The Economist Intelligence Unit. London: The Economist, 2008.

[32] R. Colenbaugh, and B. Reigel, Enabling, Engaging, and Rewarding Employees, A Study of World-at-Work Reward Professionals, 2010.

[33] S. Markos, and M. S. Sridevi, "Employee engagement: The Key to Improving Performance",
International Journal of Business and Management, vol.5, pp. 89-96, 2010.

[34] K. E. Weick, and R. E. Quinn, "Organizational Change and Development", Annual Review of Psychology, vol.50, pp. 361-386, 1999.

[35] R. A. Burgelman, "A Process Model of Internal Corporate Venturing In The Diversified Major Firm", Administrative Science Quarterly, vol.7, pp.223- 244, 1983.

[36] A.I. Frohman, "Igniting Organizational Change From Below: The Power of Personal Initiative", Organizational Dynamics, vol.25, pp.39-53, 1997.

[37] R. M. Kanter, The Change Masters, New York: Simon \& Schuster, 1983.

[38] J. Balogun, "Managing Change: Steering a Course Between Intended Strategies and Unanticipated Outcomes, Long Range Planning, vol.39, pp.29-49, 2006.

[39] E. P. Antonacopoulou, "Employee Development Through Self-Development in Three Retail Banks. Journal of Personnel Review, vol.29, pp.491-508, 2000.

[40] A. Hasan, Muhammad and A. K., Imran A. "Linkage between Employee's Performance and Relationship Conflict in Banking Scenario", International Journal of Business Management, vol.4, p.59, 2009.

[41]Kigali, Training Manual on Conflict Management, The National Unity and Reconciliation Commission: Republic of Rumanda, 2006.

[42] J. F. Medina, L. Munduate, A. D. Miguel, I. Martínez, and M. J. Guerra, "Types of Intragroup Conflict and Affective Reactions", Journal of Managerial Psychology, vol.20, pp.219-230, 2005.

[43] R. V. Krejcie, and D. W. Morgan, "Determining Sample Size for Research Activities. Educational and Psychological Measurement, vol.30, pp.607-610, 1970.

[44] D. George, and P. Mallery, Using SPSS for Windows Step By Step: A Simple Guide and Reference. Boston, MA: Allyn \& Bacon, 2003.

[45] A. B. Bakker, M. Tims, and D. Derks, "Proactive Personality and Performance: The Role of Job Crafting and Work Engagement". Human Relations, vol.65, pp.13591378, 2012.

[46] P. Petrou, E. Demerouti, M. C. W. Peeters, W. Schaufeli, and J. Hetland, "Crafting a Job on A Daily Basis: Contextual Correlates and The Link to Work Engagement", Journal of Organizational Behavior, vol.33, pp.1120-1141, 2012

[47] G. Schoenewolf, "Emotional Contagion: Behavioral Induction in Individuals and Groups", Modern Psychoanalysis, vol.15, pp.49-61, 1990. 
International Journal for Infonomics (IJI), Volume 11, Issue 4, December 2018

[48] C. Dormann, and D. Zapf, "Job Satisfaction-A Meta-Analysis of Stabilities", Journal of Organizational Behavior, vol.22, pp.1-22, 2001.

[49] M. C. Lo, and T. Ramayah, "Mentoring and Job Satisfaction In Malaysian SMEs", Journal of Management Development, vol.30, pp.427-440, 2011. 